\title{
The Paradox of Hemophilus influenzae Type B Bacteremia in the Presence of Serum Bactericidal Activity
}

\author{
Stephen Shaw, Arnold L. Smith, Porter Anderson, and \\ David H. SMrTH \\ From the Division of Infectious Diseases, Children's Hospital Medical Center \\ and the Department of Pediatrics, Harvard Medical School \\ Boston, Massachusetts 02115
}

\begin{abstract}
A в S T R A C T We investigated the role of serum bactericidal activity in Hemophilus influenzae type $\mathrm{b}$ infections in infants with meningitis and in a rat model. In infected infants, $13 / 22$ admission sera had bactericidal activity against the infecting strain, and bacteremia was as frequent in those with bactericidal activity (54\%) as in those without $(56 \%)$. The coexistence of bactericidal activity and bacteremia was reproduced and studied in experimentally infected weanling rats. Serum from such rats kills in vitro $95 \%$ of conventionally broth-grown bacteria within $10 \mathrm{~min}$, but does not kill organisms obtained from the infected animals. Thus bactericidal activity as conventionally determined for $H$. influenzae b may have no relevance in vivo. Incubation of brothgrown bacteria in normal rat serum for $30 \mathrm{~min}$ at $37^{\circ} \mathrm{C}$ produces a resistance like that of in vivo organisms. This phenotypic conversion depends on factors that are of molecular weight less than 1,000 , stable to $100^{\circ} \mathrm{C}$, but destroyed by ashing.

When injected intravenously into nonimmune animals, broth-grown bacteria are quickly cleared, while serum-preincubated bacteria are not. The latter, however, are cleared when injected into bacteremic rats (half-life $30 \mathrm{~min}$ ). Bacteremia in the rats may persist despite this capacity for clearance because bacteria are entering the blood from extravascular fluids, which contain greater than $90 \%$ of the total bacterial burden.
\end{abstract}

\section{INTRODUCTION}

In 1933, Fothergill and Wright studied the bactericidal $(B C)^{1}$ activity of whole blood from individuals of vari-

Dr. Shaw's present address is the Immunology Branch, National Cancer Institute, National Institutes of Health, Bethesda, Md. 20014.

Received for publication 15 December 1975 and in revised form 21 June 1976.

${ }^{1}$ Abbreviations used in this paper: BC, bactericidal; CSF, cerebrospinal fluid; H.i.b, Hemophilus influenzae, type $\mathrm{b}$; PBS, phosphate-buffered saline; PRP, polyribophosphate. ous ages against Hemophilus influenzae type b (H.i.b). They demonstrated the lowest activity in infants from 2 mo to $3 \mathrm{yr}$ of age, the period when children were most likely to develop H.i.b meningitis (1). From these data and supplemental studies showing that antibody and complement could account for the cidal action of blood to H.i.b in vitro, they inferred that susceptibility to H.i.b might be due to a deficiency of $\mathrm{BC}$ antibody. Since then, $B C$ assays against $H$.i.b have been used to study population immunity (2-5), immune response to infections $(6,7)$, and to vaccines $(8,9)$, with the belief that BC activity "inhibits bacteremia and dissemination" (10). There is no direct evidence, however, for the physiologic significance of serum $\mathrm{BC}$ activity against H.i.b. Assessing host immunity by BC assays has revealed inconsistencies: the incidence of infection is low in adults and newborns but in some surveys a sizeable proportion of these age groups lack detectable BC activity $(3,5)$. Feigin et al. found $\mathrm{BC}$ activity in the serum of some patients very early in the course of $H$.i.b infection, inferring that preexisting $\mathrm{BC}$ activity may not protect the host from invasion (3). However, the titers were determined against a single survey strain; since strains differ in susceptibility to $B C$ antibodies, the $B C$ activities observed may not have been active against the infecting strains.

The present study examines the significance of BC activity. Sera obtained on the day of hospital admission from 22 patients with H.i.b meningitis were assayed against the respective infecting strains. In some of the patients bacteremia was found to coexist with homologous $\mathrm{BC}$ activity. This observation prompted the examination of the phenomenon in an animal model (11). In weanling rats infected with H.i.b, bacteremia coexisted several days with an elevated $\mathrm{BC}$ titer. One possible cause of this apparent paradox is that H.i.b from the animals' blood was less susceptible to killing in the BC assay than the same strain grown in conventional me- 
dium. The basis for this variation in phenotype was explored. Additional understanding of the paradox was gained through study of the clearance of bacteria from the blood and seeding of the bacteria into the blood from extravascular foci.

\section{METHODS}

Patients. The study population consisted of 22 infants and children with culture-proven H.i.b. meningitis from whom sera were available from the same admission blood samples cultured to determine bacteremia. The ages were 2-124 mo with a median of $16 \mathrm{mo}$. The patients had had febrile illness 1-14 days before admission; 8 had been treated with antibiotics. All received ampicillin therapy and all recovered. Convalescent sera were obtained from 19 of the 22 children, 14-30 days after the admission.

Media. Brain-heart infusion broth or agar (BioQuest Div., Becton, Dickinson \& Co., Cockeysville, Md.) was supplemented as previously described (4). Phosphate-buffered saline (PBS) was previously described (4); when used as a bacterial diluent it was supplemented with $0.1 \%$ protein (bovine serum albumin in PBS-A or gelatin in PBS-G) and used at $0-4^{\circ} \mathrm{C}$.

H.i.b strains. All cerebrospinal fluid (CSF) isolates were received from the clinical bacteriology laboratory as the first subculture after primary isolation. These were streaked on agar and incubated overnight at $37^{\circ} \mathrm{C}$. Typing was confirmed by slide agglutination, and the remainder of the second subculture was suspended in sterile skim milk and frozen at $-70^{\circ} \mathrm{C}$. A fresh (third) subculture was obtained by streaking the milk suspension on agar and incubating overnight at $37^{\circ} \mathrm{C}$. The strains used in animal experiments were a meningeal isolate $(E)$, and a mutant of $\mathrm{E}$ (E-1) selected in a single step for resistance to $500 \mu \mathrm{g}$ streptomycin/ml (11).

$B C$ activity of human sera against infecting strains. The titers were determined against bacteria from exponential broth cultures inoculated from the third subculture plate as described (4). The complement source was serum of calves denied colostrum (Bacterial Products Div., Bureau of Biologics, U. S. Food and Drug Administration, Washington, D. C.). Penicillinase (BioQuest Div.) was added at 1,000 $\mathrm{U} / \mathrm{ml}$ to destroy ampicillin. As a control for nonimmunologic bactericidal effects, each serum was tested without complement and excluded from the study if positive.

Preparation of bacteria for experiments with rats. Brothgrown bacteria were used in exponential phase. In vivogrown bacteria were obtained by inoculating $10^{3}$ brothgrown organisms intraperitoneally into a weanling rat, decapitating the rat $24 \mathrm{~h}$ later, and rinsing the peritoneal cavity with $1 \mathrm{ml}$ of PBS-G. Broth- or in vivo-grown bacteria were immediately chilled to and maintained at $0^{\circ} \mathrm{C}$, then diluted with PBS-A or PBS-G and used 10-60 min after chilling. "Washed" bacteria were prepared by centrifugation at $9,000 \mathrm{~g}$ for $2 \frac{1}{2} \mathrm{~min}$ at $4^{\circ} \mathrm{C}$ in an Eppendorf model 3200 centrifuge (Brinkman Instruments, Inc., Westbury, N. Y.), decanting the supernate, and resuspending in PBS-A or PBS-G. Bacteria were "serum-incubated" by incubating washed broth-grown bacteria in normal rat serum at densities up to $2 \times 10^{\circ}$ bacteria $/ \mathrm{ml}$ at $37^{\circ} \mathrm{C}$ for $30 \mathrm{~min}$. (Bacterial suspensions were incubated in closed sterile $1-\mathrm{ml}$ Eppendorf centrifuge tubes unless otherwise noted).

Procedures with rats. Outbred pathogen-free COBS/CB rats originally obtained from Charles River Breeding Laboratories, Inc. (Wilmington, Mass.) were bred as previ- ously described (11). Pups were weaned and inoculated at 21 days of age. Bacterial suspensions for inoculation were chilled, washed, diluted, and injected $(0.1 \mathrm{ml})$ with a no. 25 gauge needle into a tail vein or into the peritoneum. An exception was the study of intravenous clearance in bacteremic animals, when the serum-incubated bacteria were maintained in the serum at $37^{\circ} \mathrm{C}$ for inoculation.

Blood for culture was obtained by lacerating the tail artery. Quantitative cultures of suspected foci of infection were performed after rapid exsanguination by cardiac puncture without anesthesia. Organ homogenates were cultured as described previously (11) with the exception that before homogenization the organs were washed with chilled PBS-G. Recovery of bacteria from body fluids was achieved as follows: peritoneal fluid, the peritoneal cavity was rinsed with $10 \mathrm{ml}$ PBS-G; intraocular fluid, the contents of the globe were expelled and mixed vigorously with $1 \mathrm{ml}$ of PBS-G; joints, fluid was aspirated from all erythematous joints and mixed with $1 \mathrm{ml}$ PBS-G; CSF, the cranial vault (together with dura and arachnoid) was dissected off and the meningeal surfaces rinsed with $1 \mathrm{ml}$ PBS-G. The total number of bacteria in each suspension was calculated by multiplying the total volume times the density of bacteria cultured from an aliquot. The animal's blood volume was assumed to be $10 \%$ of the body weight. The density of CSF infection was determined by plating a sample of the fluid film covering the meninges (before rinsing).

Rat serum preparations. Serial samples for BC assay were obtained by collecting tail artery blood in plain microcapillary tubes. Other samples were collected by rapid exsanguination by cardiac puncture without anesthesia. To assure complement preservation, all bloods were chilled immediately after clotting and centrifuged at $4^{\circ} \mathrm{C}$; the serum was stored in $2-\mathrm{ml}$ aliquots at $-70^{\circ} \mathrm{C}$. Complement activity was destroyed, where indicated, by incubation at $56^{\circ} \mathrm{C}$ for $30 \mathrm{~min}$

Pooled normal rat serum was derived from 20 normal weanling rats; its complement activity was destroyed before use. An exception was that the $100 \mathrm{ml}$ of serum analyzed by ultrafiltration was obtained from 15 normal adult rats anesthetized with ethyl ether and used with complement preserved. "Convalescent serum" was a pool from 15 rats bled 20 days after intraperitoneal inoculation with $10^{3}$ H.i.b. "Reference serum" was a pool collected from 20 weanling rats 5 days after intraperitoneal inoculation with $10^{3}$ H.i.b; bacteremia of greater than $5 \times 10^{3}$ per milliliter was verified in these rats $10 \mathrm{~h}$ before bleeding. For single use standards, reference serum was thawed and $0.050 \mathrm{ml}$ samples frozen with a dry ice bath in sterile 1-ml Eppendorf tubes, which were then stored at $-70^{\circ} \mathrm{C}$.

Serum was absorbed with bacteria by incubation for $1 \mathrm{~h}$ at $0^{\circ} \mathrm{C}$ with washed, broth-grown organisms at $10^{7}-10^{10}$ per $\mathrm{ml}$; the bacteria were removed by five centrifugations and sterility verified by culture. Serum was adsorbed with the capsular polysaccharide of H.i.b (PRP; polyribophosphate) by mixing $0.050 \mathrm{ml}$ of serum with $0.005 \mathrm{ml}$ of a $1 \mathrm{mg} / \mathrm{ml}$ solution of PRP in water and incubating for 30 min at $37^{\circ} \mathrm{C}$; because previous studies indicated no interference with the bactericidal activity of complement by this procedure (4), no effort was made to separate antigen-antibody complexes. The unabsorbed sera were incubated equivalently with water. Purified anti-PRP antibody prepared by column immunoabsorption of serum from a rabbit hyperimmunized with H.i.b was provided by Dr. R. O'Reilly.

Normal rat serum was ultrafiltered (Model 202, Amicon Corp., Scientific Systems Div., Lexington, Mass.) at $4^{\circ} \mathrm{C}$ under nitrogen at 50 pounds per square inch with an Ami- 
con UMO5 filter until $76 \%$ of the original volume had been filtered. The retentate was washed by twice restoring it to its original volume with $\mathrm{PBS}$ and repeating the ultrafiltration. $5 \mathrm{ml}$ of filtrate was ashed and then reconstituted with sterile water. The $\mathrm{pH}$ of the filtrate and the reconstituted ash were each adjusted to 7.4 with $0.2 \mathrm{~N} \mathrm{HCl}$.

$B C$ activity in rats. Dilution titers were determined as for human sera (4), except the end point was read by visual estimation of the highest dilution reducing the control number by $90 \%$. Where noted, broth-grown bacteria were replaced by a comparable suspension of washed in vivogrown bacteria.

Bacterial survival in reference serum or in freshly-drawn rat blood (anticoagulated with $1 \mathrm{U}$ heparin per milliliter) was assayed as follows: 1 part of the bacterial suspension $\left(10^{3}-10^{8}\right.$ bacteria $\left./ \mathrm{ml}\right)$ was added to 10 parts of fluid and incubated in a stationary water bath at $37^{\circ} \mathrm{C}$. Initially, and at intervals thereafter, the suspension was mixed and samples removed for determination of viable counts. Results were expressed as percentage of the initial viable count.

Kinetics of acquisition of bacterial resistance to $B C$ activity. Broth-grown bacteria were washed and diluted 1:20 in PBS-A, and $0.010 \mathrm{ml}$ was added to $0.10 \mathrm{ml}$ broth or 0.10 $\mathrm{ml}$ normal rat serum. Each suspension was incubated at $37^{\circ} \mathrm{C}$ for $30 \mathrm{~min}$, chilled on ice for $6 \mathrm{~min}$, mixed with 0.90 $\mathrm{ml}$ PBS-A, washed, and resuspended in $0.1 \mathrm{ml}$ PBS-A. A sample of $0.020 \mathrm{ml}$ of the broth-incubated suspension was added to $0.20 \mathrm{ml}$ of normal rat serum, and this mixture was divided and incubated at $0^{\circ} \mathrm{C}$ or $37^{\circ} \mathrm{C}$. At intervals, samples were taken for viable counts and for assay in reference serum. Conversely, $0.020 \mathrm{ml}$ of the normal serumincubated bacteria were added to $0.20 \mathrm{ml}$ broth; this suspension was divided, incubated at $0^{\circ} \mathrm{C}$ or $37^{\circ} \mathrm{C}$, and assayed as described.

Assay of exhancement of resistance to $B C$ activity. To $0.10 \mathrm{ml}$ of each test sample was added $0.010 \mathrm{ml}$ of PBS that contained $1 \%$ bovine serum albumin, $10 \mathrm{mM} \mathrm{CaCl}$, and $5 \mathrm{mM} \mathrm{MgCl}_{2}$. Then $0.010 \mathrm{ml}$ of a $1: 10$ dilution of washed broth-grown bacteria in PBS-A was added, and the tube was mixed, incubated at $37^{\circ} \mathrm{C}$ for $30 \mathrm{~min}$, and chilled to $0^{\circ} \mathrm{C}$ for $6 \mathrm{~min}$. A sample was then assayed for bacterial survival in reference serum. Serial twofold dilutions of complement-inactivated normal rat serum in PBS were used as standards; PBS was used as a control. A standard curve was constructed by plotting bacterial survival vs. serum dilution. For each test sample, the concentration of normal serum producing the same bacterial survival was quoted as that sample's specific activity. The filtration coefficient, $k$, for the resistance-enhancing substance was calculated from the formula $k=\ln (c f) / \ln (v f)$ where $v f=$ the fraction of the original volume present in the filtrate, and $c f=$ the fraction of the substance which appears in the filtrate; derivation of this formula assumes that the concentration of the substance in the fluid being filtered at any instant is a constant fraction $k$ of that substance's concentration in the retentate.

Measurement of PRP and anti-PRP antibody. Serum antibodies to PRP were titered by radioantigen binding (12). The content of soluble PRP in the serum-incubated or broth-incubated H.i.b cultures (approx. $10^{\circ} / \mathrm{ml}$ ) was estimated by adding formaldehyde to $0.4 \%$, holding the suspension for 5 days at room temperature, centrifuging, and assaying the supernate for PRP by radioantigen-binding inhibition (12).

Statistical methods. The statistical significance of data was tested by $t$ test and chi-square test with Yates' correction.

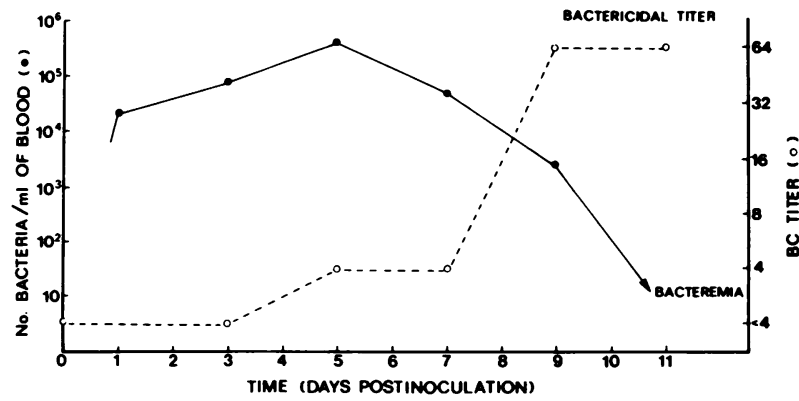

FIGURE 1 The time course of $H$. influenzae bacteremia and serum bactericidal titers in a weanling rat. Data is representative of a nonimmune rat after intravenous injection of $10^{\circ}$ organisms on day zero. The arrow indicates that organisms were not present at the limit of detection $\left(10^{2} / \mathrm{ml}\right)$.

\section{RESULTS}

Antibody activity and bacteremia in humans with H.i.b meningitis. Data on the 22 patients studied are given in Table I. On admission, bacteremia was demonstrated in 12 of the 22 patients. BC activity against the strain recovered from the CSF was demonstrable in the sera of 13 patients but not in the remaining 9, even in serum dilutions as low as $1: 1.2$. The prevalence of bacteremia was similar in patients with $\mathrm{BC}$ activity (54\%) and those without $(56 \%)(P>0.9)$. The highest admission BC titer observed was $1: 8$, in a bacteremic patient.

Bacteremia was somewhat less frequent with short preceding illness, with prior antibiotic therapy, and when anti-PRP antibody was demonstrable, but these differences were not statistically significant. Antibiotic pretreatment was more common in the nonbacteremic patients $(50 \%)$ than in the bacteremic ones $(25 \%)(P \cong$ $0.6)$. Antibody activity to the capsular polysaccharide PRP, determined by radioantigen binding, generally was undetectable or very low in the admission sera, but was found more frequently in the nonbacteremic patients $(55 \%)$ than in the bacteremic ones $(14 \%)(P \cong 0.3)$. Excluding the atypical patient with prolonged treated illness (no. 8), the duration of preceding illness was generally longer in the bacteremic patients (mean $=3.8$ days) than in the nonbacteremic patients (mean $=2.0$ days) $(P \cong 0.15)$.

Coexistence of $B C$ activity and bacteremia in weanling rats. Bacteremia (greater than 100 organisms per milliliter) persisted in five weanling rats for at least 7 days after intravenous inoculation of $10^{\circ}$ organisms. Each animal developed a BC titer of at least $1: 4$ by the 5 th day postinoculation; thus each had a period of at least 2 days during which $\mathrm{BC}$ titers of at least $1: 4$ coexisted with bacteremia (Fig. 1). When the inoculum size and route of administration was $10^{3}$ bacteria given intraperitoneally, BC titers reached $>1: 16$ by day 5 (five of five animals) and bacteremia persisted at least 2 days 
TABLE I

Antibody Activity and Bacteremia in Children with H.i.b. Meningitis

\begin{tabular}{|c|c|c|c|c|c|c|}
\hline \multirow[b]{2}{*}{ Case } & \multicolumn{2}{|c|}{ Preadmission } & \multicolumn{3}{|c|}{ Data on admission blood sample } & \multirow[b]{2}{*}{$\begin{array}{c}\text { Convalescent } \\
\text { BC titer }\end{array}$} \\
\hline & $\begin{array}{c}\text { Days } \\
\text { ill }\end{array}$ & $\begin{array}{l}\text { Anti- } \\
\text { biotics* }\end{array}$ & $\begin{array}{l}\text { BC } \\
\text { titer } \ddagger\end{array}$ & $\begin{array}{c}\text { Anti-PRP } \\
\text { titer }\end{array}$ & $\begin{array}{l}\text { H.i.b. } \\
\text { cultured }\end{array}$ & \\
\hline & & \multicolumn{5}{|c|}{$n g / m l$} \\
\hline 1 & 4 & - & 8 & ND\& & + & 64 \\
\hline 2 & 1 & - & 2 & $\mathrm{ND}$ & + & 2 \\
\hline 3 & 7 & $\mathrm{Am}, \mathrm{Cf}$ & 1.2 & $<7.0$ & + & ND \\
\hline 4 & 2 & - & 1.2 & ND & + & ND \\
\hline 5 & 7 & - & 1.2 & $<7.0$ & + & 4 \\
\hline 6 & 2 & - & 1.2 & 60 & + & 2 \\
\hline 7 & 3 & $\mathbf{P}$ & 1.2 & ND & + & 1.2 \\
\hline 8 & 14 & Am & 1.2 & 34 & - & 2 \\
\hline 9 & 3 & - & 1.2 & 59 & - & 64 \\
\hline 10 & 4 & Am, $\mathbf{P}$ & 1.2 & $<7.0$ & - & 2 \\
\hline 11 & 1 & - & 1.2 & 34 & - & 8 \\
\hline 12 & 3 & $\mathrm{Am}$ & 1.2 & ND & - & 1.2 \\
\hline 13 & 1 & - & 1.2 & $<7.0$ & - & 4 \\
\hline 14 & 1 & - & $<1.2$ & $<7.0$ & + & 2 \\
\hline 15 & 1 & - & $<1.2$ & $<7.0$ & + & 1.2 \\
\hline 16 & 7 & - & $<1.2$ & $<7.0$ & + & 2 \\
\hline 17 & 7 & Am, $\mathbf{P}$ & $<1.2$ & $<7.0$ & + & $<1.2$ \\
\hline 18 & 3 & - & $<1.2$ & ND & + & $<1.2$ \\
\hline 19 & 3 & Am & $<1.2$ & 18 & - & 8 \\
\hline 20 & 1 & Am & $<1.2$ & $<7.0$ & - & 1.2 \\
\hline 21 & 1 & - & $<1.2$ & 12 & - & $>64$ \\
\hline 22 & 1 & - & $<1.2$ & $<7.0$ & - & ND \\
\hline
\end{tabular}

* Am, ampicillin; Cf, cephalothin; $P$, penicillin.

$\ddagger$ Against patient's CSF isolate.

$\$ \mathrm{ND}$, not determined.

thereafter. The latter method and the 5th postinoculation day were chosen for further study of the coexistence of bacteremia and BC activity; animals so prepared are hereafter called "bacteremic" rats.

$A$ difference between broth-grown and in vivo bacteria. Strain E-1 bacteria grown in broth were added to blood obtained from bacteremic rats (i.e., with endogenous strain E) and the survival of both bacterial populations was examined during incubation at $37^{\circ} \mathrm{C}$. The endogenous bacteria survived and grew (Fig. 2). In contrast, there was a two-log decrease in the viable count of the broth-grown bacteria. To rule out possible strain-dependent effects, the experiment was repeated with reversal of strains, and the results were similar. After a 30-min incubation the mean survival (four experiments) was $130 \%$ for endogenous bacteria and $0.8 \%$ for broth-grown bacteria. The possibility that the endogenous bacteria survive in vivo because they are intracellular was excluded by recovery of greater than 95\% of the circulating bacteria from cell-free plasma.
Bacterial survival was then studied during in vitro incubation in serum from bacteremic rats (hereafter called "reference serum"); bacteria harvested from the peritoneal cavity ("in vivo-grown" bacteria) were used in place of the endogenous bacteria, which had been removed by centrifugation. As in the studies with whole blood, the in vivo-grown bacteria survived (mean of $120 \%$ in four experiments), while the broth-grown bacteria were killed within 30 min (mean survival $2 \%$ ). Thus, in vivo-grown and broth-grown bacteria differ in their susceptibility, and reference serum can be a reagent for differentiating the two. The designation "resistant" was applied to bacterial populations, such as those grown in vivo, which survived in reference serum. The designation "sensitive" was applied to populations, such as those grown in broth, of which greater than $95 \%$ were killed by reference serum. The possibility that the viable count of sensitive bacteria decreased in reference serum because of agglutination (13) was ruled out: the percentage survival was con- 


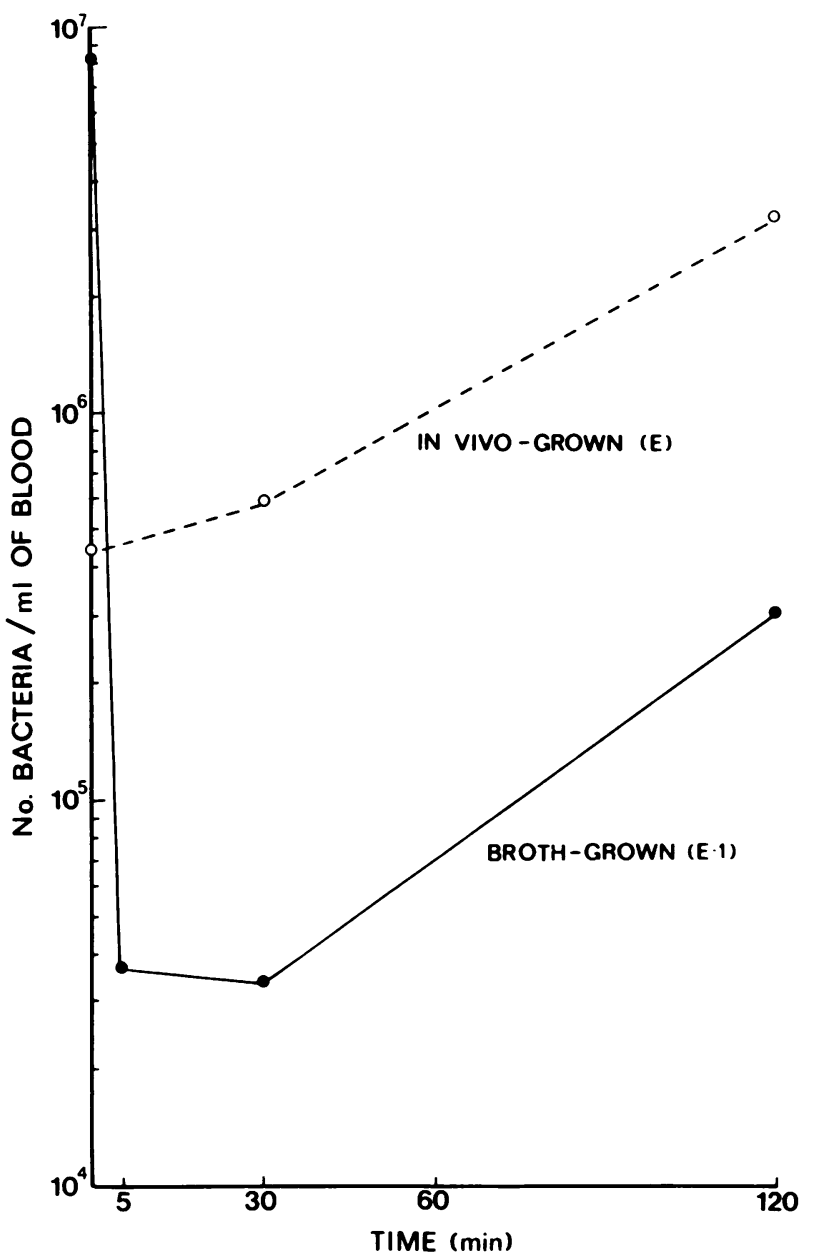

Figure 2 Differing survival of phenotypic variants of $H$. influenzae in blood from bacteremic rats. A weanling rat was inoculated intraperitoneally with $10^{3} \mathrm{H}$. influenzae (strain E, open circles). 5 days later the infected blood was obtained by cardiac puncture and broth-grown bacteria (strain E-1, closed circles) were added; the mixture was then incubated at $37^{\circ} \mathrm{C}$. Viable counts of strains $\mathrm{E}$ and $\mathrm{E}-1$ were differentiated by plating on media with and without streptomycin at $500 \mu \mathrm{g} / \mathrm{ml}$.

stant $(1.9-2.6 \%)$ over a wide range of bacterial concentrations $\left(10^{5}-10^{8} / \mathrm{ml}\right)$, and no clumping was visible on microscopic examination of gram-stained smears of the incubation mixtures. Control studies showed that both antibody and complement were required for the killing of sensitive bacteria : the titer of reference serum was abolished by absorption with the homologous strain, and activity was eliminated by heating but restored with an antibody-free fresh serum. The susceptibility of sensitive (in vitro-grown) and resistant (in vivogrown) bacteria to various antiserum preparations was then compared. Normal serum (Table II, no. 1) had no activity against either. Antibody directed against the capsular antigen PRP (no. 6) had equal activity against
TABLE II

The Activity of Different Antisera Preparations against "Resislant"* and "Sensitive" $\ddagger$ Bacteria

\begin{tabular}{|c|c|c|c|}
\hline Source & $\begin{array}{l}\text { Preincuba- } \\
\text { tion with } \$ \\
\text { PRP }\end{array}$ & $\begin{array}{l}\text { vs. } \\
\text { Resistant* } \\
\text { bacteria }\end{array}$ & $\begin{array}{c}\text { vs. } \\
\text { Sensitiveł } \\
\text { bacteria }\end{array}$ \\
\hline 1 Normal animals\| & - & $<4$ & $<4$ \\
\hline 2 Bacteremic animals $\llbracket$ & - & $<4$ & 32 \\
\hline 3 Bacteremic animals & + & $<4$ & 32 \\
\hline 4 Convalescent animals** & - & 8 & 32 \\
\hline 5 Convalescent animals & + & 8 & 32 \\
\hline 6 Normal animals + anti-PRP $¥$ & - & 128 & 128 \\
\hline 7 Normal animals + anti-PRP & + & $<4$ & $<4$ \\
\hline
\end{tabular}

* Bacteria harvested from the peritoneum of infected rat.

$¥$ Bacteria grown in broth in vitro.

$\$$ Sera incubated with PRP before BC assay designated by + , controls indicated by -

|| Normal 21-day-old rats.

II 26-day-old rats, 5 days after infection with H.i.b.

** 41-day-old rats, 20 days after infection with H.i.b.

\# Same sera as no. 1, supplemented with $1 / 100$ volume of purified rabbit anti-PRP.

both bacterial populations. Bacteremic animals (reference serum, no. 2) had acquired BC activity only against sensitive bacteria, while convalescent animals (20 days after infection, no. 4), had acquired some BC activity against the resistant organisms as well.

Preincubation with PRP did not alter the $\mathrm{BC}$ activity in bacteremic or convalescent sera (nos. 3,5 ), and antiPRP antibody as determined by radioantigen binding was undetectable or very low (not tabulated). Thus, antigens other than PRP must account for the susceptibility of both populations of bacteria to these rat sera.

Generation of resistant bacteria in vitro. It was observed that sensitive bacteria became resistant during incubation in normal rat serum. Conversely, resistant bacteria became sensitive during incubation in broth. The kinetics of acquisition and loss of resistance are shown in Fig. 3. Sensitive bacteria were incubated in normal rat serum at $37^{\circ} \mathrm{C}$, and samples were transferred into reference serum to determine bacterial survival. Increased resistance was apparent at $6 \mathrm{~min}$ and complete by $36 \mathrm{~min}$. In a similar manner, samples were assayed periodically during the incubation of resistant bacteria in broth. Some loss of resistance was observed at 20 min, but loss was not complete until $4 \mathrm{~h}$. Generation time was about $30 \mathrm{~min}$ in both media. Thus, bacteria growing in normal rat serum became resistant in approximately one generation time, while bacteria growing in broth lost resistance over several generations.

To explore whether metabolic processes were required for these changes in bacterial phenotypes, the incubations outlined above were also conducted at $0^{\circ} \mathrm{C}$. There was very little acquisition of resistance (1\% survival rising to $4 \%$ survival) during incubation in serum at $0^{\circ} \mathrm{C}$ for $60 \mathrm{~min}$, and there was no loss of resis- 


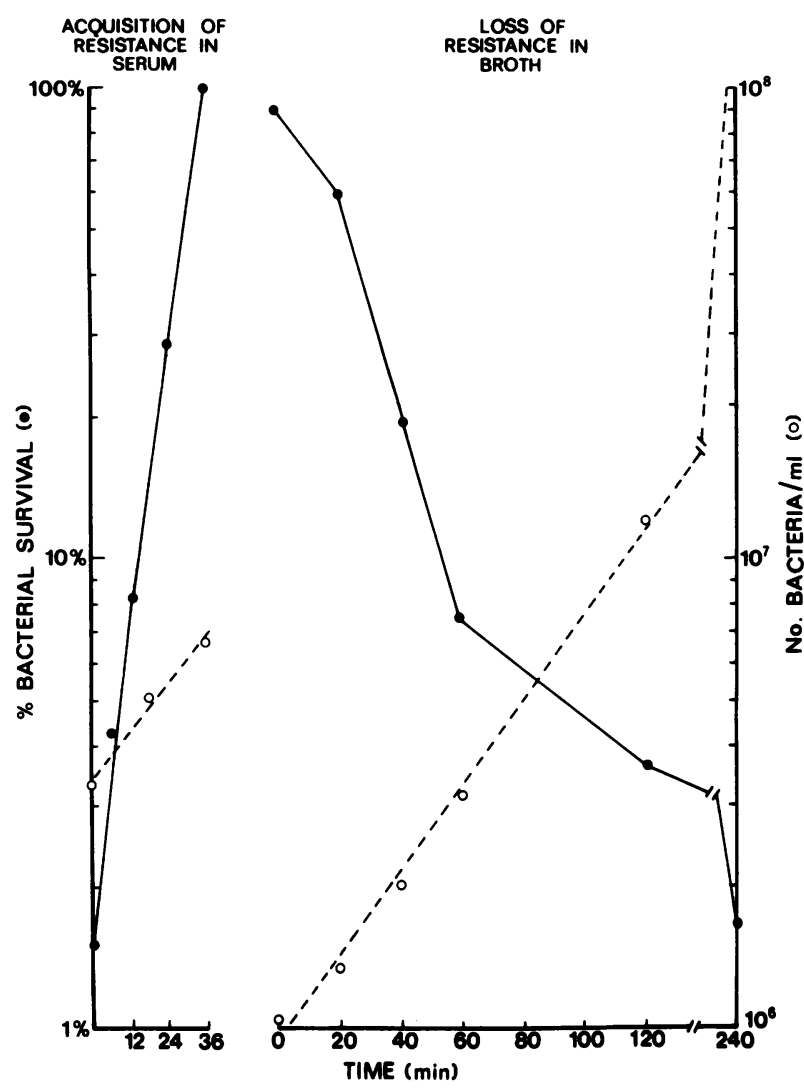

FIGURE 3 The rate at which $H$. influenzae acquires and loses resistance to serum bactericidal activity. The resistance to a bactericidal activity is expressed as the percentage of bacteria that survived a $30-\mathrm{min}$ incubation in "reference serum". Left, resistance and viable counts during the incubation of broth-grown organisms in serum. Right, similar assays during incubation of serum-grown organisms in broth. The points represent the means of two experiments.

tance during incubation in broth at $0^{\circ} \mathrm{C}$ for $60 \mathrm{~min}$. The resistance acquired by incubation in serum at $37^{\circ} \mathrm{C}$ was not reduced by three cycles of centrifugation and vigorous resuspension in serum-free medium at $0-4^{\circ} \mathrm{C}$. Also, the sensitive and resistant bacterial preparations were compared for content of soluble PRP; both contained $0.1 \mathrm{ng} / 10^{\circ}$ cells as estimated by radioantigen binding inhibition (12).

Attempts were made to characterize the factors in rat serum responsible for the enhanced resistance. It was found that the appropriate diluent in which to assay serum fractions for enhancement of resistance was buffered saline (PBS) containing calcium and magnesium ions and a dilute protein supplement (albumin $0.1 \%$ ). Broth was not used a a diluent, since it was found to inhibit the acquisition of resistance when mixed with serum. After preliminary studies showed the resistanceenhancing factor(s) to be dialysable, the molecular size was estimated by ultrafiltration through a membrane with a nominal molecular weight cut-off of 500 daltons
(Table III). Recovery of the original activity was $100 \%$. The filtrate, which had $76 \%$ of the original volume, contained $60 \%$ of the total activity. The filtration coefficient calculated from these data is 0.6 , which indicates that the filter is relatively unable to retain the substance(s) in rat serum responsible for enhancing resistance. Moreover, when the retentate was diluted and refiltered as described, its total activity was reduced to less than $10 \%$ of the starting material. The activity of the ultrafiltrate was unchanged by heating at $100^{\circ} \mathrm{C}$ for 30 min but was destroyed by ashing.

In vivo studies. The behavior in vivo of the two different phenotypes of H.i.b was first studied in nonimmune animals. Suspensions of sensitive and resistant bacteria were inoculated into weanling rats, and clearance was followed with quantitative blood cultures. Approximately $70 \%$ of the sensitive bacteria were cleared in $10 \mathrm{~min}$ (Fig. 4). In contrast, there was no detectable clearance of the resistant bacteria. Thus, the phenotypic difference observed in vitro correlated with a difference in the rate of clearance in vivo.

Resistant bacteria were then used to study intravascular clearance in bacteremic rats (i.e., after 5 days of infection with strain $\mathrm{E}$ ). The animals were injected intravenously with serum-treated strain E-1 and the counts of both the endogenous and the injected bacteria examined. The counts of endogenous organisms remained constant (Fig. 5). In contrast, the number of injected organisms decreased by $95 \%$ over $2 \mathrm{~h}$. After slightly accelerated clearance in the first $10 \mathrm{~min}$, the decrease in viable counts of injected organisms was exponential, with a half-life of $25-30 \mathrm{~min}$. Reversal of the strains, i.e., endogenous E-1 and injected E, gave qualitatively similar results; however, the small numbers of $\mathrm{Str}^{\mathrm{s}}$ bacteria could not be quantitated among the large numbers of $\operatorname{Str}^{\mathbf{R}}$.

The constancy of the number of endogenous bacteria could be accounted for in either of two ways. It is pos-

TABLE III

The Effect of Ultrafultration* on the Ability of Normal Rat Serum to Enhance Bacterial Resistance

\begin{tabular}{lccc}
\hline Solution & Volumet & $\begin{array}{c}\text { Specific } \\
\text { activity }\end{array}$ & $\begin{array}{c}\text { Total } \\
\text { activity } \|\end{array}$ \\
\hline Filtrate & 0.76 & 0.8 & 0.6 \\
Retentate & 0.24 & 1.6 & $\frac{0.4}{1.0}$ \\
Total & $\underline{1.00}$ & &
\end{tabular}

* Ultrafiltration through Amicon UM05 membrane.

$\ddagger$ Volume of solution/total volume.

$\$$ The activity of the solution or dilutions thereof in making bacteria resistant to the bactericidal activity of serum from bactermic rats (compared to standard of 1.0 for serum before filtration).

$\|$ Computed as volume $X$ specific activity. 
sible that endogenous bacteria eluded clearance because they differed phenotypically in some unknown way from the injected bacteria. Alternatively, both bacterial populations may have been cleared similarly, but the expected fall in viable count of endogenous bacteria was being masked by the continuous entrance of new organisms into the blood from extravascular foci. Evidence for the latter possibility was found by culturing body fluids and tissue homogenates from bacteremic rats. In all eight animals studied, large numbers of bacteria were recovered from body fluids other than blood. In all instances, the bacteria in blood represented less than $7 \%$ of the total bacterial burden. Infected extravascular sites included CSF, peritoneal fluid, intraocular fluid, and joint fluid (Table IV). Meningitis was probably present in

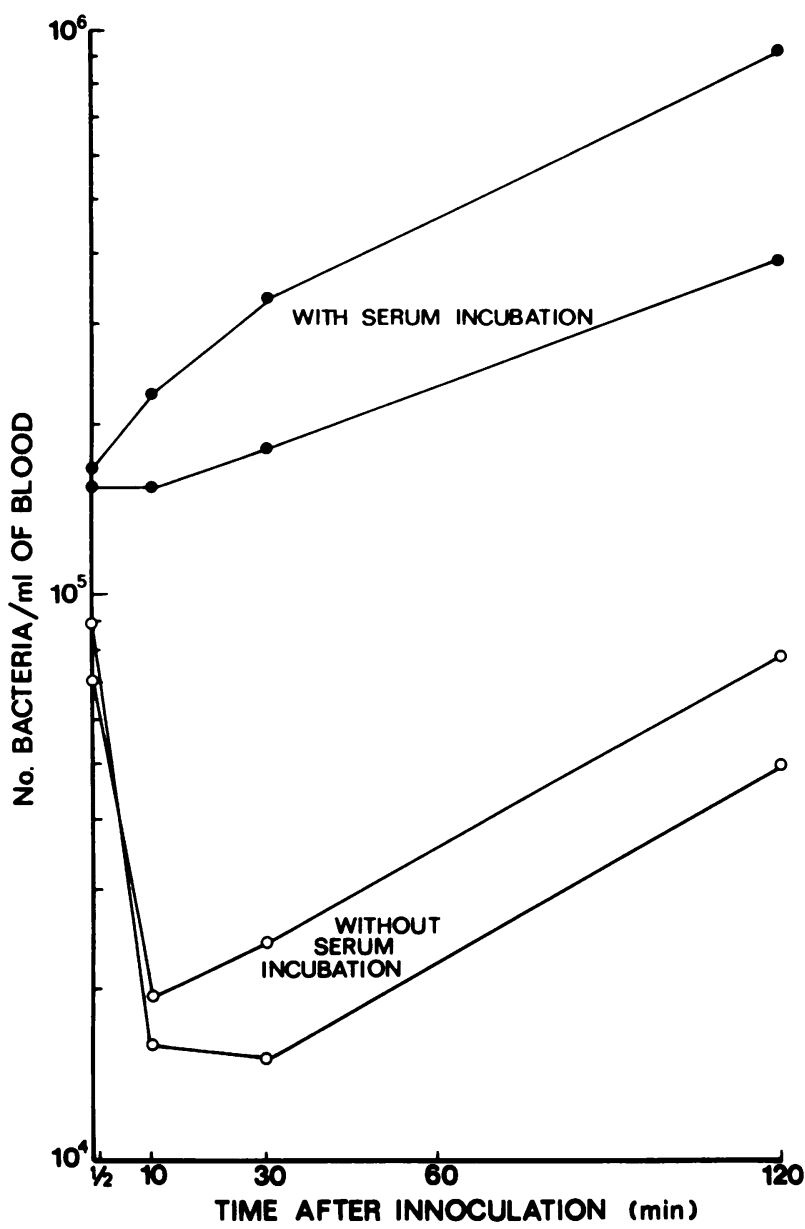

FIGURE 4 The influence of incubation in serum on subsequent intravenous clearance of $H$. influenzae in normal rats. Normal weanling rats were inoculated intravenously with "sensitive" (open circles) or "resistant" (closed circles) phenotypes of $H$. influenzae. Both strains were grown in broth, but the resistant preparation was incubated in normal rat serum at $37^{\circ} \mathrm{C}$ for $30 \mathrm{~min}$ before injection. Each curve depicts a single animal.

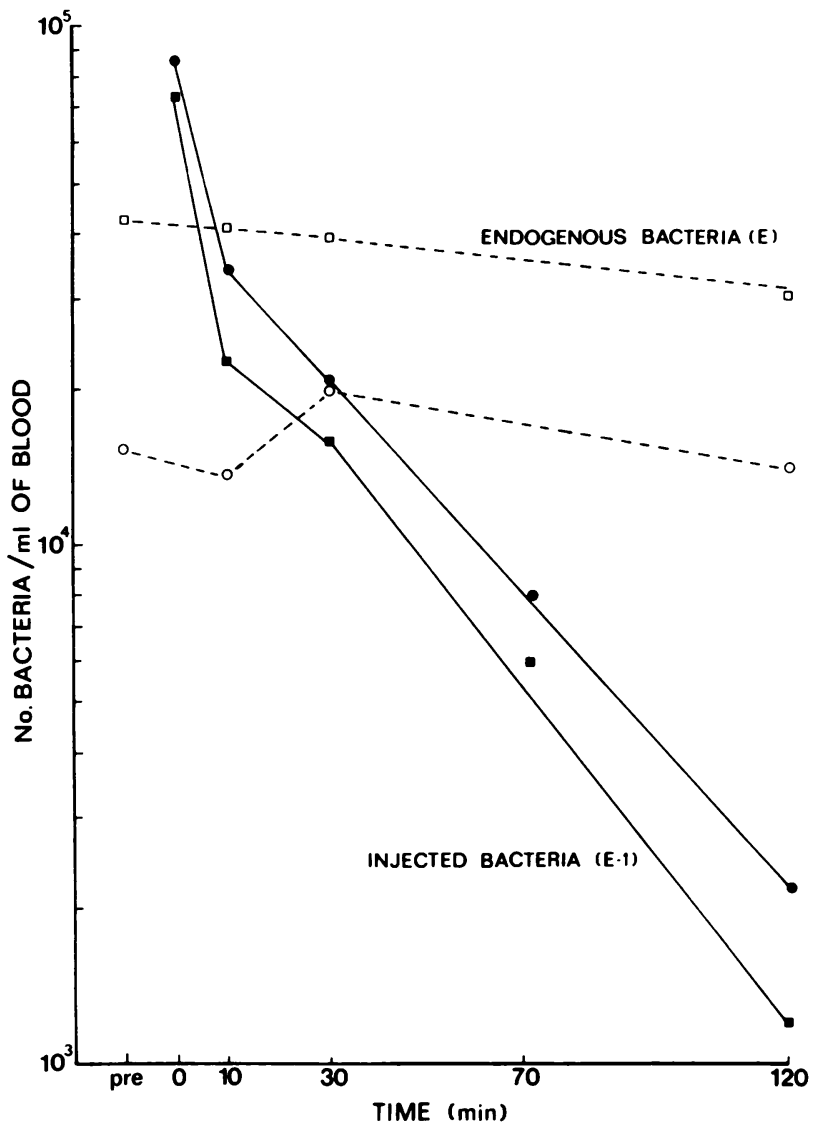

FIGURE 5 The clearance of serum-incubated bacteria in bacteremic rats. A pair of weanling rats was inoculated intraperitoneally with $10^{3} \mathrm{H}$. influenzae, strain E. 5 days later serum-incubated strain E-1 was injected intravenously, and the viable count in the blood of the endogenous and the injected bacteria determined.

five of the eight rats which had CSF bacterial densities ranging between 2 and 250 times that in the blood. In two animals the CSF was sterile. In the remaining animal the number of bacteria in the CSF was half that of blood, which might be a reflection of meningitis, or might be an experimental artifact caused by blood contamination.

In liver, spleen, kidney, lung, brain, and muscle, the number of bacteria per gram of homogenized organ was always less than one-half, and usually less than onefifth of the number in $1 \mathrm{ml}$ of blood. It is probable that this recovery of bacteria reflected the content of bacteremic blood in uninfected organs; however, these data do not rule out the possibility of low density tissue infection.

\section{DISCUSSION}

Serum BC activity to $H$.i.b had been found in acute sera of patients with systemic diseases caused by this species, but the activity was measured against a single 
TABLE IV

Bacterial Densilies in Body Fluids in Eight Weanling

Rats 5 Days after Intraperitoneal Inoculation of $10^{3} \mathrm{H}$. Influenzae

\begin{tabular}{lccl}
\hline \multicolumn{1}{c}{ Fluid } & $\begin{array}{c}\text { No. of } \\
\text { animals with } \\
\text { infected fluid }\end{array}$ & \multicolumn{2}{c}{$\begin{array}{c}\text { Percent of total } \\
\text { bacterial burden* }\end{array}$} \\
\hline Blood & 8 & 1.5 & $(0.2-6)$ \\
CSF & 6 & 0.11 & $(0-0.26)$ \\
Peritoneal & 6 & 37 & $(0-99)$ \\
Intraocular & 5 & 60 & $(0-99)$ \\
Joint & 1 & $1.1 \quad(0-9.3)$ \\
\hline
\end{tabular}

* Number of bacteria in fluid $(\times 100) /$ total cultured from the animal, averaged for the eight animals (range among individual animals).

strain (3). Since isolates of H.i.b may differ in susceptibility to a particular serum, our study was performed with the patients' infecting strains. The data of Table I indicate that bacteremia can occur in the presence of homologous $\mathrm{BC}$ activity. This observation implies that such specimens were taken just as antibody was being made or that serum $B C$ activity may not deter bacteremia.

By studying an experimental infection of weanling rats, we found that H.i.b bacteremia and $\mathrm{BC}$ activity can coexist several days (Fig. 1). Two phenomena contribute to this apparent paradox: first, the elevated $\mathrm{BC}$ titer can be an in vitro artifact due to a difference in bacterial phenotype, and second, the entrance of bacteria into the blood from densely infected extravascular fluids can sustain the bacteremia despite continuous clearance of bacteria from the blood.

It is well documented that organisms grown in vitro may be phenotypically different from those in vivo (14). Increased resistance of in vivo-grown organisms to phagocytosis has been reported for Brucella abortus (15). Increased resistance to serum BC activity has been reported for Neisseria gonorrhoeae (16) and decreased resistance for Pasteurella multocida (17). The present study demonstrates that H.i.b grown in rats or in rat serum are more resistant to host defenses than when grown in broth. When compared in BC assays, the former survive in sera which kill $95 \%$ of the latter. When compared in vivo, in intravenous clearance studies, the former survive in normal animals while greater than $70 \%$ of the latter are cleared. Since broth-grown organisms are used in the conventional assays of serum BC antibody, the activity observed in vitro may be an artifact which does not pertain to bactericidal activity in vivo. Incubations in broth and in rat serum were identical in respect to a number of variables known to change the susceptibility of a given strain to serum BC activity: growth phase (18), $\mathrm{pH}$ (19), temperature
(18), or added drugs (20). The factor(s) in rat serum causing the phenotypic change is not yet identified. The low activity of the washed retentate from serum ultrafiltration, and the filtration coefficient of 0.6 through a membrane with a nominal cutoff of 500 daltons suggests that the active factor(s) is of molecular weight less than 1,000 . Thus antibody $(21,22)$ or exogenous enzymes (23) do not appear to be effecting the transformation. The destruction of activity by ashing suggests that it is not mediated by changes in the nature or concentration of inorganic ions $(19,24)$.

Newman et al. (25) noted that during BC assays the presence of nutrients adequate for growth made H.i.b more resistant to serum. This does not explain the difference between resistant and sensitive bacteria, since both were growing vigorously before the assay, and both had the same nutrition during the assay. (Rat serum is nutritionally complete for H.i.b). Maalфe (26) noted that the survival of Salmonella typhimurium was dependent upon the choice of nitrogen and carbon sources and their concentrations in the media in which bacteria were grown before the $\mathrm{BC}$ assay. The susceptibility of H.i.b may be similarly dependent upon the concentration of specific metabolites which vary among complete media.

The mechanism by which the serum factor(s) increases the bacterial resistance is also unknown. With Shigella dysenteriae the effect of small molecules on susceptibility to $\mathrm{BC}$ activity may be mediated by their adsorption onto the bacterial surface (27), However, with H.i.b the persistence of the enhanced resistance despite washing, and the failure of serum to enhance resistance at $0^{\circ} \mathrm{C}$ suggest that the change results through metabolism, not from passive adsorption. One possibility was a difference in content of PRP, for mutations reducing its synthesis increase susceptibility of H.i.b to the BC activity of non-PRP-directed antibodies (4), and mutational and phenotypic loss of PRP increases the rate of intravascular clearance in normal rats. ${ }^{2}$ In the present study, however, the preparation of resistant bacteria did not contain more PRP than the sensitive. Thus, the difference in phenotypes is not attributable to differences in bacterial PRP content. However, differences in the surface distribution of PRP were not excluded.

The resistant phenotype hypothetically could resist any stage of the bactericidal sequence. Decreased antibody-binding could result from changes in the surface antigens or in their accessibility to antibody (28). Decreased complement fixation, (independent of antibodybinding) could result if the cell surface became anticomplementary, similar to $\mathrm{K}$ antigen function in $E s$ -

\footnotetext{
${ }^{2}$ Weller, P. F., A. L. Smith, P. Anderson, and D. A. Smith. 1976. J. Infect. Dis. In press.
} 
cherichia coli (29). Decreased membrane damage by complement could result from surface alterations which produced complement fixation at a greater distance from the cell membrane (30). Finally, decreased loss of viability could result if altered metabolic activity allowed better repair of complement-mediated damage (31).

If the phenotypic change were one which affected the $\mathrm{BC}$ sequence at or after complement fixation, it would be expected to alter bacterial susceptibility to all complement-mediated BC activity. Since the change involves increased resistance to only certain antibodies (reference serum but not anti-PRP), it is probable that the mechanism of resistance enhancement involves a change in antibody binding. One appealing hypothesis is that some substances in rat serum stimulate bacterial production of a material which overlies a critical antigen, $\mathrm{A}$, on the bacterial surface. Consequently, the bactericidal antibody (anti-A) in reference serum no longer binds and kills. Growth in broth would result in dilutional loss of the surface material, concomitant exposure of antigen $\mathrm{A}$, and restored $\mathrm{BC}$ susceptibility. This postulated behavior occurs in bacterial mutants which depend on exogenous sugars to produce complete $O$-side chains (32). When the requisite sugar is added to media lacking it, bacteria elongate their $O$-side chains and lose their reactivity with certain antibodies. Although we have been unable to demonstrate that similar blocking of antigenic determinants occurs during incubation of H.i.b in serum, all available data are consistent with this hypothesis.

Seeding of extravascular bacteria into the blood perpetuates bacteremia in rats by balancing immune clearance of bacteria. The evidence for this dynamic equilibrium can be outlined as follows: (a) Resistant H.i.b are rapidly cleared from the blood of bacteremic animals ( $\mathrm{t}_{1}$ of 30 min, see Fig. 5). (b) Clearance of circulating bacteria presumably occurs at the same rate. (The incubation in rat serum assured that the injected bacteria would resemble in vivo bacteria. Furthermore, if in vivo bacteria had a phenotype which escaped clearance, cessation of clearance would be expected as the injected bacteria acquired this phenotype; cessation of clearance was not evident during the $2 \mathrm{~h}$ of observation). (c) The failure to observe a fall in viable count of circulating organisms could be explained by rapid entrance of bacteria into the blood from extravascular foci. (d) Such extravascular foci were found in bacteremic animals, and contained the majority $(>93 \%)$ of bacteria present. (e) Rapid entrance of bacteria into the blood from such foci has been demonstrated in a similar model; in 5-day-old rats, approximately $15 \%$ of a peritoneal inoculum was seeded into the blood in $1 \mathrm{~h}(11)$. ( $f$ ) The seeding of about $1 \%$ of the extravascular bacteria into the blood each hour would balance the calculated clearance in the "average" rat, while $10 \%$ seeding $/ \mathrm{h}$ would explain the most extreme case.

From this analysis of the data, the distribution of bacteria in an "average" animal after 5 days of infection would be $10^{4}$ organisms/ml of blood (about $10^{5}$ total intravascular bacteria) and $10^{\circ}$ organisms present in extravascular fluids (such as peritoneal fluid or intraocular fluid). Of the extravascular bacteria, about $1 \%\left(10^{5}\right.$ organisms) migrate into the blood every hour. Concurrently the bacteria in the blood are cleared with a halflife of $30 \mathrm{~min}$, resulting in a clearance of $10^{5}$ organisms/h. The net result of this dynamic flux of bacteria is a constant bacteremia of $10^{4}$ organisms $/ \mathrm{ml}$. If seeding from extravascular foci persisted, then even a 100 -fold increase in the rate of bacterial clearance (corresponding to a bacterial half-life of $20 \mathrm{~s}$ ) would still be accompanied by a bacteremia of $10^{2}$ organisms $/ \mathrm{ml}$. Thus, sterilization of the blood stream depends not only on rapid clearance of bacteria from the blood, but also on eradication of extravascular foci from which seeding is occurring.

The clearance of resistant bacteria from the blood of bacteremic rats is probably not the result of destruction by circulating phagocytes, since whole blood is unable to kill the endogenous bacteria in vitro. More likely the fixed phagocytes are responsible. Since clearance of resistant bacteria did not occur in nonimmune animals, clearance probably depends on opsonization by specific antibody; however, nonspecific activation of the $\mathrm{RE}$ system (phagocytosis independent of antibody) or of the alternate complement pathway have not been ruled out.

It is noteworthy that the location of septic foci in this animal model is principally in fluids (peritoneal, intraocular, cerebrospinal, and joint fluids) rather than tissues. Similarly, in the common human infections with H.i.b bacteria may be recovered in high titer from infected body fluids. This prediliction is poorly understood, but probably in such fluids H.i.b, like other encapsulated bacteria, is less susceptible to nonspecific phagocytosis (33).

The relation of the animal model findings to human immunity to H.i.b remain to be established. Immediate questions are whether such a phenotypic change occurs in response to factors in human blood, in relation to human antibodies, and in other or all strains of H.i.b. If the phenomenon were demonstrable, one could ponder whether it has affected the outcome of the various BC assays heretofore employed in human studies. Questions remain about the bactericidal action of antibody and complement: is the mechanism itself important in host defense against H.i.b, and is the in vitro assay a useful index of immunity?

Operation of the bacteriolytic mechanism in vivo has not been established or disproven. From previous ob- 
servations that bacteria can be cultured from the blood despite $\mathrm{BC}$ activity of the serum against the same strain, the inference was made that "the action of serum in vivo is much less effective than testing in vitro would indicate" (34). The validity of such observations would be enhanced by ruling out phenotypic differences (as in the H.i.b-rat model) that artifactually increase susceptibility in vitro. It is of interest that blood from bacteremic rats was unable to kill in vitro the bacteria that were circulating in vivo (Fig. 2), even though the animals were able to clear comparable bacteria from circulation (Fig. 5). Thus clearance from circulation appears not to require $\mathrm{BC}$ activity. The rats, however, eventually developed $\mathrm{BC}$ activity effective against in vivo-grown bacteria (Table II, no. 4), so the data do not rule out a contribution of bacteriolysis to eventual resolution of the infection.

$\mathrm{BC}$ assays in vitro detect complement-fixing antibody directed against bacterial surface antigens. With Neisseria meningitidis such antibodies have been found in prospective studies to correlate strongly with host resistance (35); whether the antibodies act in vivo by bacteriolysis, opsonization. or by some other mechanism, the $\mathrm{BC}$ assay is a useful in vitro index of immunity. Since H.i.b infections occur endemically and primarily in infants, such prospective studies are difficult to achieve. Statistical surveys of normal populations have the uncertainty of strain variation. while studies on patients at presentation (such as the present) suffer the uncertainty of how long the patient has been in contact with the bacterial antigens. To these problems it may become necessary to add the complication of phenotypic discrepancies of the type here described, further increasing misgivings about the validity of conventional $\mathrm{BC}$ assays as in index of immunity to H.i.b.

\section{ACKNOWLEDGMENTS}

The authors are grateful to Doctors Harvey Colten and Paul Quie for valuable discussions, and to Lynn Harding and Barbara Emerson for technical assistance.

This investigation was supported by National Institute of Allergy and Infectious Diseases Contract 71-2196 and a grant from Eli Lilly and Company, Indianapolis, Ind.

\section{REFERENCES}

1. Fothergill, L. D., and J. Wright. 1933. Influenzal meningitis. The relation of age incidence to the bactericidal power of blood against the causal organism. J. Immunol. 24 : 273-284.

2. Gump, D. W., P. Tarr, C. A. Phillips, and B. R. Forsyth. 1971. Bactericidal antibodies to Hemophilus influenzae. Proc. Soc. Exp. Biol. Med. 138: 76-80.

3. Feigin, R. D., D. Richmond, M. W. Hosler, and P. G. Shackelford. 1971. Reassessment of the role of bactericidal antibody in Hemophilus influenzae infection. $\mathrm{Am}$. J. Med. Sci. $262:$ 338-346.
4. Anderson, P., R. B. Johnston, Jr., and D. H. Smith. 1972. Human serum activities against Hemophilus influenzae, type b. J. Clin. Inz'est. 51: 31-38.

5. Norden, C. W. 1974. Prevalence of bactericidal antibodies to Hemophilus infuenzac, type b. J. Infect. Dis. 130: 489-494.

6. Norden, C. W., and R. Michaels. 1973. Immunologic response in patients with epiglottitis caused by Hemophilus influenzae, type b. J. Infect. Dis. 128: 777-780.

7. Norden, C. W., M. Melish, J. C. Overall, Jr., and J. Baum. 1972. Immunologic responses to Hemophilus influenzae meningitis. J. Pediatr. 80: 209-214.

8. Smith, D. H., G. Peter, D. L. Ingram, A. L. Harding, and P. Anderson. 1973. Responses of children immunized with the capsular polysaccharide of Hemophilus influenzae, type b. Pediatrics. 52: 637-644.

9. Schneerson, R., and J. B. Robbins. 1975. Induction of serum Hacmophilus infucnzae, type b capsular antibodies in adult volunteers fed cross-reacting Escherichia coli 075 :K100:H5. N. Engl. J. Mcd. 292: 1093-1096.

10. Klein, J. O. 1970. Haemophilus influenzae infections. In Practice of Pediatrics. J. Brenneman, editor. Harper \& Row, Publishers, New York. II (Part 1): 1-10.

11. Smith, A. L., D. H. Smith, D. R. Averill, Jr., J. Marino, and E. R. Moxon. 1973. Production of Haemophilus influcnzae b meningitis in infant rats by intraperitoneal inoculation. Infect. Immun. 8: 278-290.

12. O'Reilly, R. J., P. Anderson, D. L. Ingram, G. Peter, and D. H. Smith. 1975. Circulating polyribophosphate in Hemophilus influcnzae, type $\mathrm{b}$ meningitis. Correlation with clinical course and antibody response. J. Clin. Inz'est. 56: 1012-1022.

13. Melching, L., and S. I. Vas. 1970. The effects of serum components on the agglutination of gram-negative bacteria. Can. J. Microbiol. 16: 121-124.

14. Smith, H. 1964. Microbial behavior in natural and artificial environments. Symp. Soc. Gen. Microbiol. 14: $11-29$.

15. Smith, H., and R. B. Fitzgeorge. 1964. The chemical basis of the virulence of Brucella abortus. V. The basis of intracellular survival and growth in bovine phagocytes. Br. J. Exp. Pathol. 45: 174-186.

16. Ward, M. E., P. J. Watt, and A. A. Glynn. 1970. Gonococci in urethral exudates possess a virulence factor lost on subculture. Nature (Lond.). 227: 382-384.

17. Bain, R. V. S. 1960 . Mechanism of immunity in haemorrhagic septicemia. Nature. (Lond.). 186: 734-735.

18. Davis, S. D., and R. J. Wedgewood. 1965. Kinetics of the bactericidal action of normal serum on gram-negative bacteria. J. Immunol. 95: 75-79.

19. Wardlaw, A. C. 1962. The complement-dependent bacteriolytic activity of normal human serum. I. The effect of $\mathrm{pH}$ and ionic strength and the role of lysozyme. $J$. Exp. Med. 115 : 1231-1249.

20. Feingold, D. S. 1969. The serum bactericidal reaction. IV. Phenotypic conversion of Escherichia coli from serum-resistance to serum-sensitivity by diphenyamine. J. Infect. Dis. 120: 437-444.

21. Hall, W. H., R. E. Manion, and H. H. Zinneman. 1971. Blocking serum lysis of Brucella abortus by hyperimmune rabbit immunoglobulin A. J. Immunol. 107: 41-46.

22. Waisbren, B. A., and I. Brown. 1966. A factor in the serum of patients with persisting infection that inhibits the bactericidal activity of normal serum against the organism that is causing the infection. J. Immunol. 97: 431-437. 
23. Chedid, L., M. Parant, F. Parant, and F. Boyer. 1968. A proposed mechanism for natural immunity to enterobacterial pathogens. J. Immunol. 100: 292-301.

24. Reynolds, B. L., and D. Rowley. 1969. Sensitization of complement resistant bacterial strains. Nature (Lond.). 221: 1259-1261.

25. Newman, S. L., B. Waldo, and R. B. Johnston, Jr. 1973. Separation of serum bactericidal and opsonizing activities for Hemophilus influenzae, type b. Infect. Immun. 8: $488-490$.

26. Maaløe, O. 1948. Pathogenic-apathogenic transformation of Salmonella typhimurium. II. Induced change of resistance to complement (continued). Acta Pathol. Microbiol. Ccand. 25 : 755-766.

27. Michael, J. G., and W. Braun. 1959. Modification of bactericidal effects of human sera. Proc. Soc. Exp. Biol. Med. 102: 486-490.

28. Rowley, D. 1968. Sensitivity of rough gram-negative bacteria to the bactericidal action of serum. J. Bacteriol. 95 : $1647-1650$.

29. Glynn, A. A., and C. J. Howard. 1970. The sensitivity to complement of strains of Escherichia coli related to their $\mathrm{K}$ antigens. Immunology. 18: 331-346.

30. Rowley, D., and K. J. Turner. 1968. Passive sensitization of Salmonella adelaide to the bactericidal actoin of antibody and complement. Nature (Lond.). 217: 657-658.

31. Melching, L., and S. I. Vas. 1971. Effects of serum components on gram-negative bacteria during bactericidal reactions. Infect. Immun. 3: 107-115.

32. Medearis, D. N., Jr., B. M. Camitta, and E. C. Heath. 1968. Cell wall composition and virulence in Escherichia coli. J. Exp. Med. 128: 399-414.

33. Wood, W. B., Jr. 1960. Phagocytosis, with particular reference to encapsulated bacteria. Bacteriol. Rev. 24: $41-49$.

34. Roantree, R. J., and N. C. Pappas. 1960. The survival of strains of enteric bacilli in the blood stream as related to their sensitivity to the bactericidal effect of serum. J. Clin. Invest. 39 : 82-88.

35. Goldschneider, I., E. C. Gotschlich, and M. S. Artenstein. 1969. Human immunity to the meningococcus. I. The role of humoral antibodies. J. Exp. Med. 129: 1307-1326. 